\title{
The Impact of Energy De-Subsidization Policy in 2030: A Dynamic CGE Model in China
}

\author{
Wei Li ${ }^{1,2 *}$, Hongzhi Zhang ${ }^{1}$, Shu Zhang ${ }^{1}$ \\ ${ }^{1}$ School of Economics and Management, North China Electric Power University, Baoding, Hebei, China \\ ${ }^{2}$ Philosophy and Social Science Research Base of Hebei Province, North China Electric Power University, \\ Baoding, Hebei, China
}

Received: 17 January 2018

Accepted: 16 April 2018

\begin{abstract}
The issues of energy shortage and environmental pollution caused by energy subsidies are more serious in a massive energy-consuming country like China. Since the Group of 20 summit meeting on September 4, 2016, government leaders have confirmed that they will phase out inefficient fossil fuel subsidies. In this paper, we construct a computable general equilibrium model to analyze the impact of different de-subsidization policies based on possible reduction targets, mitigation routes, and reform periods. The results show that a nonlinear tendency in gross domestic product will emerge with the increasing intensity of de-subsidization targets. Moreover, there is a general macroeconomic recession both in output and consumption, where the prices have generally increased. The results also show that various mitigation routes of de-subsidization policy are slightly significant economically. However, the total removal of energy subsidy in one year will obtain an opposite conclusion with better social welfare and gross domestic product, but more carbon emissions and energy consumption. Overall, a medium target (50-90\%) with an average reduction during 2010-2030 could be more suitable for China.
\end{abstract}

Keywords: energy de-subsidization policy, China, computable general equilibrium (CGE) model, price-gap approach, energy subsidy

\section{Introduction}

Today's portfolio of fossil energy production and increasing energy consumption go against a sustainable vision for the world's development [1]. Energy subsidy, though initially designed to alleviate energy poverty [2] and lower the costs of domestic production [3], has caused an excessive energy consumption inescapably, which has led to social conflicts, environmental pollution, and even corruption [4]. On the other hand,

*e-mail: ncepulw@126.com inefficient energy subsidies could have negative effects on economic growth and social welfare [5-7], and may lead to untargeted and a non-transparent energy market [8-11] and heavy financial burden issues [12-14]. Therefore, there has been a rising academic query about whether energy subsidies need to be reserved and how to reduce them legitimately. Since the Group of 20 (G20) summit meeting in Hangzhou, it has been agreed internationally that inefficient fossil fuel subsidies that encourage wasteful consumption should be phased out. China has made remarkable achievements in economic growth and urbanization during these years, where energy supply and consumption played a promoting 
role. Therefore, energy subsidy issues are worthy of being paid more attention.

Available studies on energy de-subsidization policy focus on the impact and scale of removing energy subsidies. Coady and Newhouse (2006) [15] discovered that a $50 \%$ increment in domestic fuel prices caused a $4.6 \%$ decrement in real income that occurred based on the subsidy reform in five developing countries. According to Bazilian and Onyeji (2012) [16], fossil fuel subsidy removal policies led to an economically inefficient allocation of resources and market distortions with a focus on the implications for businesses. Accompanying the increase in energy price by the removal of subsidies, poor families suffered more [17] and had only $8 \%$ endurance capacity compared to rich families [18]. Lin and Li (2012) [19] found that China would suffer negative externalities and a certain harm to output through the removal of subsidies. Though these studies inferred that energy de-subsidization policy could lead to a certain recession in macroeconomics, much literature has also obtained positive opinions. The International Energy Agency (IEA) has emphasized the need for energy de-subsidization policy with the positive effect of alleviating global energy-related $\mathrm{CO}_{2}$ emissions [2]. Nastaran and Abbas (2012) [20] figured out that complete removal of energy subsidies could potentially reduce gas consumption by 85 billion cubic meters over the next 20 years. According to Arias and Beers (2013) [21], empirical results have shown that reducing energy subsidies in Organization for Economic Co-operation and Development (OECD) countries can promote the popularity and application of renewable energy. Moreover, Planet (2014) [22] found out that if the subsidies were replaced by lump-sum transfers of equal value, social welfare could be significantly higher. And Siddig et al. (2013) [23] also interpreted that a transfer of income to poor families could alleviate some of the negative impacts on households under a de-subsidization policy. Lin and Jiang (2011) [24] also discovered that if the energy removals were reallocated into certain production sectors, the positive effects would be macroeconomic. Based on the price-gap approach, Li (2011) [25] discovered that $\mathrm{CO}_{2}$ emissions can be cut to 62.15 million tons with the removal of the fossil fuel subsidy in 2007 , and $¥ 386.40$ billion can be saved to relax the government financial crisis.

However, few researchers have studied the subsidy reduction progress on both renewable energy and fossil fuels. Moreover, most researchers have focused on the total removal of fossil fuel subsidies and ignored the long-term characteristics and flexibility of this energy policy. Therefore, the impact of energy de-subsidization policy during 2010-2030 is considered based on the various subsidy reduction targets, mitigation routes, and reform periods for a better government policy design. The computable general equilibrium (CGE) model and price-gap approach are adopted to simulate the energy de-subsidization policy and calculate the energy subsidies in China. As a popular policy simulation tool in these years, the CGE model has seen incomparable dominance on analyzing the macroeconomic impact of government policies or behaviors [26-29]. This paper will first clarify the general overview of energy subsides in China. And then we estimate the scale of China's energy subsidies in 2010 based on the pricegap approach. The estimated energy subsidies will be adopted as an important variable of the CGE model and then the CGE model will be constructed. Finally, we build 15 scenarios to simulate and analyze the impact of energy de-subsidization policy.

\section{Material and Methods}

\section{Energy Subsidies in China}

\section{Price-Gap Approach}

In recent years the price-gap approach has been widely used in measuring the scale or effects of subsidies in the energy sector by international institutions and nations, because of its low data requirements and simple calculation procedure. In the price-gap approach, different subsidies on energy consumption will finally reflect on the impact of consumer price levels, and the scales of the energy subsidies can also be calculated based on the fluctuating extent of energy prices and the amount of energy consumption [26]. China, along with other developing countries, lacks a completed systematic statistical data in the renewable energy sector. Therefore, the price-gap approach has been adopted in this CGE model in order to analyze the scale and effects of energy subsidies in China. The consumer price and reference price are determined in the following.

\section{Price gap $=$ reference price - consumer price}

And the amount of energy subsidies is calculated by the following equation, where $\mathrm{E}$ is specific energy consumption.

$$
\text { Subsidies }=\text { price }- \text { gap } \times E
$$

\section{Energy Price}

1) Coal prices. During the period 1980-2014, coal consumption covered almost $70 \%$ of energy consumption of China every year (Fig. 1.). It cannot be denied that China is still experiencing a coal-dominated energy structure and may have remained in this situation for a long time. China's coal subsidies were mainly at thermal coal, which accounted for even more than 50\% of the national coal consumption from 2006 to 2010 [27]. Because of the sharply increased demand for coal, Qinhuangdao Port has become the world's largest coal transfer terminal in 1989. After decades of expansion 


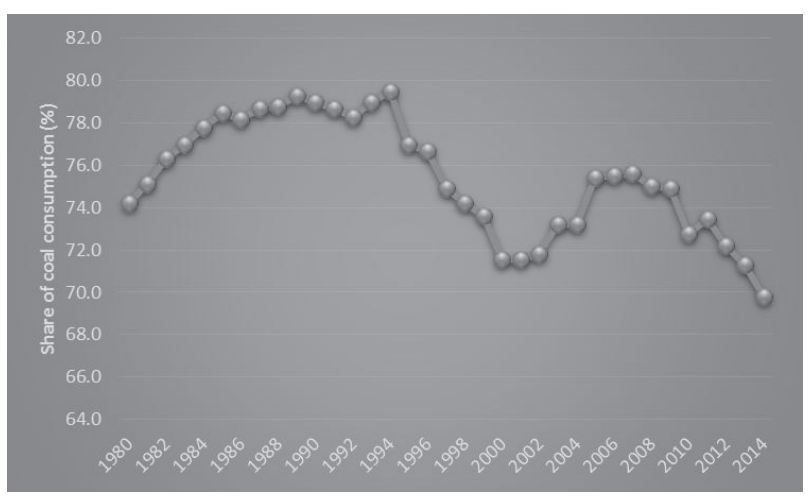

Fig. 1. Coal consumption proportion a in China ${ }^{\mathrm{a}}$

a Source based on the data in China Energy Statistical Yearbook (2015), adjusted by calorific value calculation.

and development, Qinhuangdao Port has been authorized by the National Development and Reform Commission (NDRC) [31] to publish the Bohai-Rim Steam-Coal Price Index (BSPI) since 2010. Therefore, coal prices at Qinhuangdao Port are officially representative of domestic coal prices. In this paper, the average free on board (FOB) prices of Qinhuangdao steam coal and the average shipping costs of coal from Qinhuangdao to Shanghai, Guangzhou, and Zhangjiagang have been adopted as the reference prices of coal. And the average thermal coal prices have been regarded as consumer prices of coal. The reference prices and consumer prices of coal are listed in Table 1.

2) Prices of oil products. Before 1998, the Chinese government completely dominated the domestic prices of oil products. Along with the increase of oil product consumption, the government had to adjust the oil products pricing policy to adapt to the development of market economics. In 2009, the pricing and tax reforms on oil products came to an end. Based on the new pricing reforms on oil products, when the international market price of crude oil is less than $528 \mathrm{CNY}$ per barrel (conversion by the exchange rate of CNY against USD in 2010), oil products prices are settled by the normal profit rate; when the price is higher than $528 \mathrm{CNY}$ a barrel, oil product prices are settled by a zero processing profit. In this paper, we choose the FOB prices from Platts, adding the exclusive tax of oil products as the reference prices of domestic oil products and the retail prices determined by the NDRC as the consumer prices of oil products (Table 1).

3) Natural gas prices. Natural gas price in China have long been in government control. Ex-factory price, distribution, and transmission costs are not available because of the government price control. Due to the lack of natural gas resources and poor marketization process in the pricing system, the price of natural gas in China is far higher than the average international price. Therefore, liquefied petroleum gas is adopted as an alternative fuel to calculate the reference price of natural gas in this paper, instead of the average price of natural gas in North America. The reference price and consumer price of natural gas are listed in Table 1.

4) Electricity tariffs. The electricity tariff is also administratively regulated by the government [28]. The subsidy procedure of electricity always remains complicated, delayed, and hard to measure. The electricity tariff is comprised of four parts: the transmission and distribution price, pool purchase price (PPP), and retail power price. However, the PPP of renewable energy generation and fossil fuel generation has a dramatic difference as a result of scale effects and technical costs. Hence then, the reference price of renewable energy generation cannot be reflected by the fossil energy generation. According to the International Monetary Fund (IMF, 2013) [32], as a non-traded energy production, the appropriate reference of renewable energy generation should be the cost recovery price of domestic producers, including the normal return of

Table 1. Reference prices and consumer prices of energy ${ }^{\mathrm{a}}$.

\begin{tabular}{|c|c|c|c|c|c|}
\hline & & & Consumer price & $\begin{array}{l}\text { Reference price of domestic } \\
\text { production }\end{array}$ & $\begin{array}{l}\text { Reference price of } \\
\text { import }\end{array}$ \\
\hline Coal & $\mathrm{CNY} /$ ton & & 712.72 & 810.96 & \\
\hline Gasoline & $\mathrm{CNY} /$ ton & & 8596.44 & 8898.73 & 9582.38 \\
\hline Diesel oil & $\mathrm{CNY} /$ ton & & 7335.92 & 7689.36 & 8184.22 \\
\hline Fuel oil & $\mathrm{CNY} /$ ton & & 4573.39 & & 5729.90 \\
\hline \multirow{2}{*}{ Natural gas } & \multirow{2}{*}{$\mathrm{CNY} / \mathrm{M}^{3}$} & Industry & 2.88 & 5.51 & \\
\hline & & Resident & 2.47 & 5.51 & \\
\hline \multirow{4}{*}{ Electricity } & \multirow{4}{*}{$\mathrm{CNY} / \mathrm{MWh}$} & Fossil fuel generation & 512.09 & 1131.92 & \\
\hline & & Solar Pv & 512.09 & 2552.65 & \\
\hline & & Wind power & 512.09 & 1197.19 & \\
\hline & & Biomass & 512.09 & 1393.41 & \\
\hline
\end{tabular}

${ }^{a}$ The calculated data is adopted from the research of Lin and Ouyang (2014) [27]. 


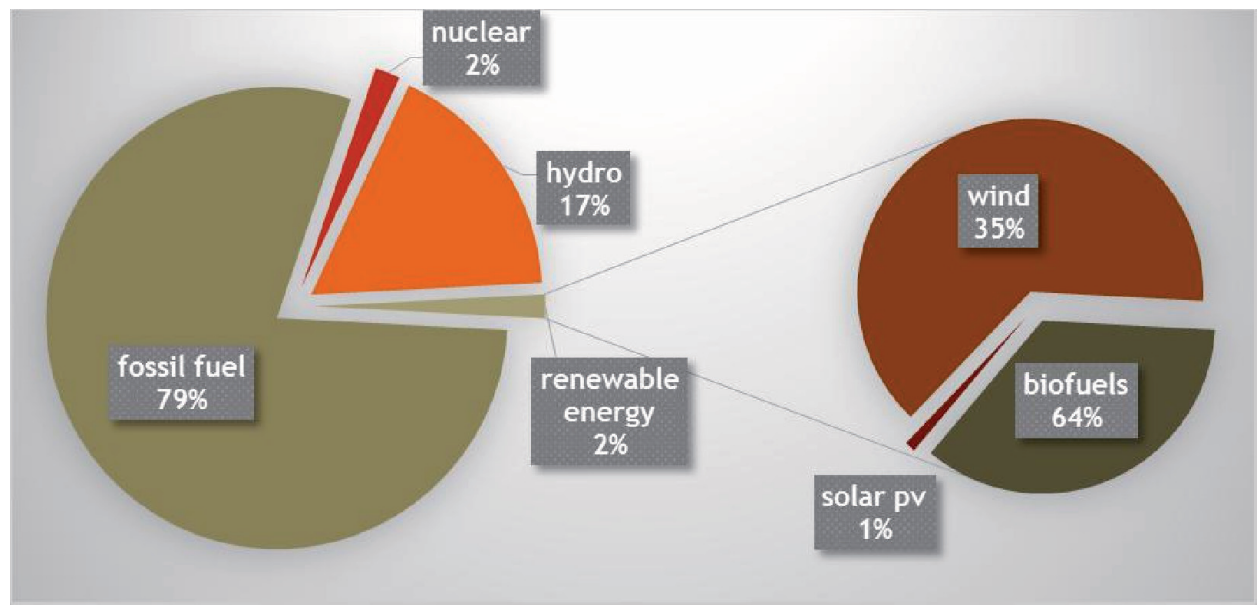

Fig. 2. Power generation structure in 2010 (IEA statistics).

investment and transportation costs. For this reason, a leveled cost of electricity (LCOE) is adopted as the reference price of renewable energy power. Ouyang and Lin (2014) [33] first systematically studied the LCOE of renewable energy under different discount rates in China. In this study, in order to better estimate the scale of energy subsidy in electricity, the LCOE of renewable energy under a $10 \%$ discount rate added the exclusive tax is adopted as the reference price of renewable energy generation. The reference of fossil fuel generation is adopted from the estimation of the Asia Development Bank and adjusted by CPI (consumer price index). The reference price of both renewable energy and fossil energy is listed in Table 1. It should first be noted that, in the case of the double counting problem in calculating energy subsidies, the electricity subsidy is focused on household electricity. That is to say, subsidies calculated by coal, oil products, and natural gas are used to represent the subsidies on electricity from the production side. Secondly, the accuracy of energy subsidies during 2010-2030 is not the main target in this paper. Energy subsidy measured by the standard coal of each kind of energy is just regarded as an estimation way to explore the impact of energy de-subsidization policy. Thirdly, consistency assumptions in electricity are adopted in this paper. For example, the quality of electricity consumed at different times of day is regarded as the same kind of power generation, which means it's not divided into renewable energy generation or fossil fuel generation. Fourthly, according to the Renewable Energy Law (2005), hydropower generation is not applied to the renewable energy subsidy policy, which is focused on wind, solar, and biomass power generation. The power generation structure in 2010 is shown in Fig. 2.

\section{Estimates of Energy Subsidies in 2010}

Based on the results in Table 1, equations (1) and (2) are applied to estimate the scale of Chinese energy subsidies in terms of the price-gap approach. Each type of energy subsidy is listed in Table 2. As shown in Table 2, the scale of energy subsidies in 2010 was 967.51 billion CNY, which accounts for $2.34 \%$ of gross domestic product (GDP). As a matter of fact, fossil fuel subsidies shared $99 \%$ of energy subsidies. Due to the development of renewable energy in the initial stage, the financial pressure brought about by energy subsidies was mainly focused on fossil fuel. According to the China Financial Yearbook, fiscal expenditure in 2010 was 8987.42 billion CNY, of which for education, science and technology, social security and employment and environment protect were 1225, 325.02, 913.06 and 244.2 billion CNY respectively. Therefore, the results have truly demonstrated that energy subsidies have

Table 2. Scale of energy subsidies in 2010 (billion/CNY).

\begin{tabular}{|c|c|c|c|c|c|}
\hline Coal & Gasoline oil & Diesel oil & Fuel oil & Natural gas & Electricity \\
\hline 306.74 & 20.82 & 52.61 & 43.46 & 292.23 & 251.66 \\
\hline
\end{tabular}

Table 3. Energy subsidies calculated by standard coal in 2010 (CNY/tce).

\begin{tabular}{|c|c|c|c|c|c|}
\hline Coal & Gasoline oil & Diesel oil & Fuel oil & Natural gas & Electricity \\
\hline 137.53 & 205.44 & 246.74 & 809.54 & 2042.46 & 1215.52 \\
\hline
\end{tabular}


brought a huge burden on national financial activities. For the purpose of estimating the CGE model, energy subsidies have been converted to a standard coal subsidy in order to estimate the effect of de-subsidization policy, which is listed in Table 3.

\section{Methodology}

Due to the interdependent and increasingly complex economic system, the computable general equilibrium (CGE) model, which deeply relies on standard microeconomic theory, is especially applicable in empirical economic analysis, energy consumption, and greenhouse gas emission analysis, such as global warming [34], macro-influence of economic system development, and reform [35, 36], evaluation, and impact of environmental policy implementation [37,38]. In this study, the CGE model is used to analyze the effect of energy de-subsidization policy on the environmental and economic system in China during 2010-2030. And the CGE model framework is based on the previous research [39]. Four blocks have been built in this paper: production, income-expenditure, market, and energy subsidy policy blocks. This macroeconomic system of mathematical equations is modeled and solved by the general algebraic modeling system (GAMS), which is an advanced modeling system software for solving mathematical programming problems.

\section{Production Block}

The production block represents the structure of the production functions, which is shown in Fig. 3. We assume that each producer (represented by an activity) aims to maximize profits, which are maximized subject to a production technology and each activity produces one or more commodities according to fixed yield coefficients. A commodity may be produced by more than one activity. A nested constant elasticity of substitution (CES) function has been applied for production activities. However, at the top level, there is output composition that is specified by a Leontief function of the quantities of energy and value-added (VAE) bundle, aggregate intermediate input. VAE bundle is nested by valued added (VA) bundle and energy input. VA bundle is composed of labor and capital and energy input is constituted by non-oil and oil product bundles, both of which are CES functions. Crude oil is not discussed in the CGE model because of a perfectly competitive international market. Relatively, the difference of oil products (such as gasoline oil, diesel oil, and fuel oil) between the prices of international market and domestic supply is significant. The oil products are nested with the CES functions of gasoline, diesel, and fuel oil. In this paper, under consideration of the development and application of renewable energy in China, photovoltaic

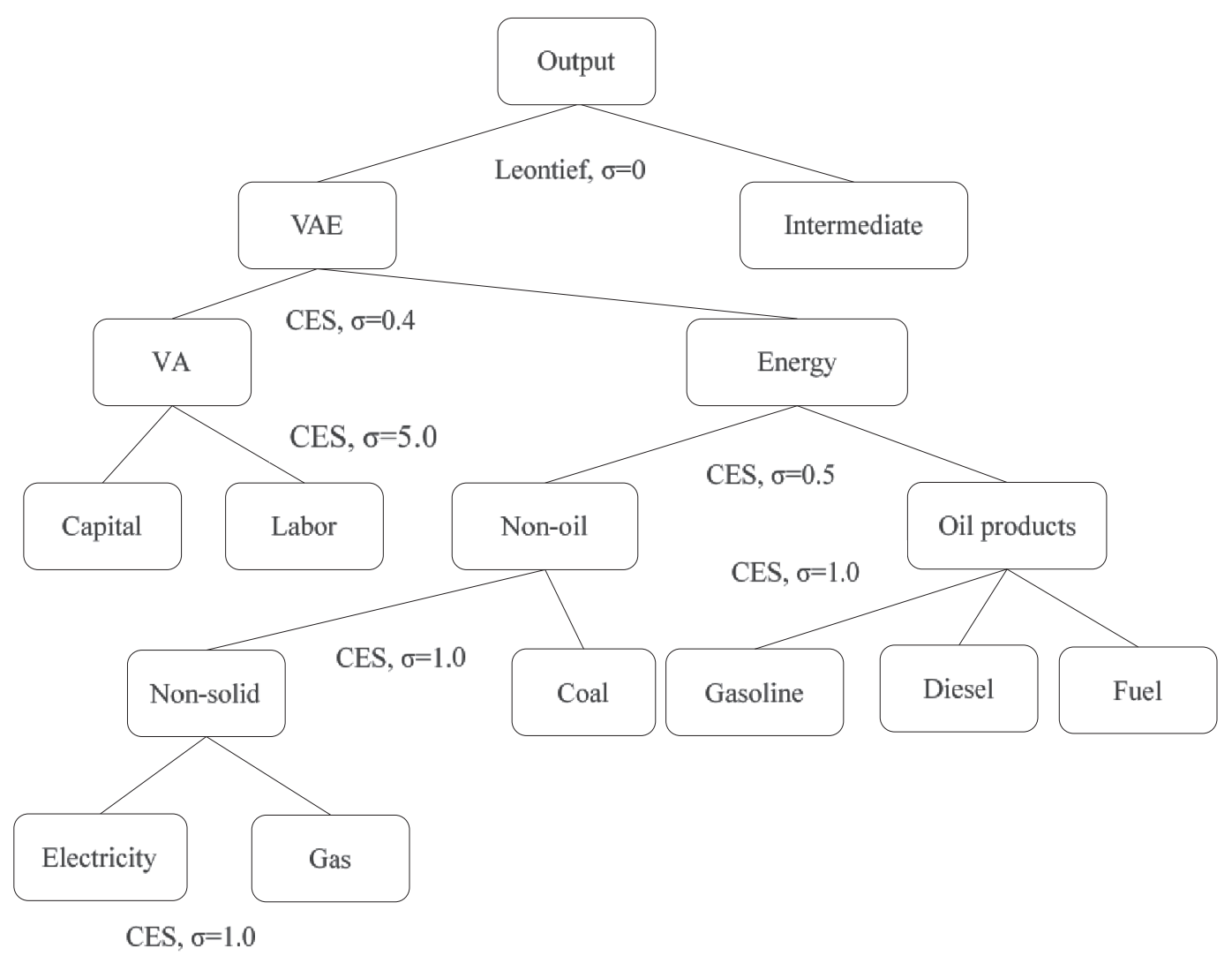

Fig. 3. Production block framework. 
power, wind power, and hydroelectricity are the main part of the renewable energy sector.

\section{Income-Expenditure Block}

The second block is the income-expenditure block, which constitutes households, enterprises, the government, and the rest of the world (foreign), as shown in Fig. 4. The households receive income from the factors sold to the enterprises under the assumption that there are no self-consumption behaviors in households. The households use their income after taxes, savings, and transfers to other institutions to support the consumption of commodities, throughout the different combinations of various commodities to achieve utility maximization. Cobb-Douglas (CD) functions have been applied to interpret household behaviors in this CGE model. Domestic enterprises determine how much of each factor the economy devotes to the production of each commodity for the purpose of profit maximization. Enterprise incomes are allocated to direct taxes, savings, and transfers to other institutions. In this study, government behavior mainly contains taxation and government consumption. All the tax revenue the government receives from direct tax, indirect tax, tariff, and transfer payments is totally used for government consumption. The government consumes all the commodities in the market at a fixed consumption tendency. The rest of the world, for example foreign enterprises, buy the domestic commodities and sell foreign-made commodities to the domestic institutions.

\section{Market Block}

The next block is the trade block. As an open macroeconomic model, the difference between domestic commodities and imported and exported commodities should have been considered. Therefore, Armington assumption is used to interpret the imperfect substitutability relationship between domestic commodities and imported commodities and exported commodities. CES functions have been applied to represent the Armington composite commodities (ACC), which is composed of imported commodities and relevant domestic commodities:

$$
\begin{aligned}
D_{i} & =\left[\frac{\gamma_{i}^{\eta_{i}} \delta d_{i} P Q_{i}}{P D_{i}}\right]^{\frac{1}{1-\eta_{i}}} Q_{i} \\
M_{i} & =\left[\frac{\gamma_{i}^{\eta_{i}} \delta m_{i} P Q_{i}}{\left(1+\tau_{i}^{m}\right) P M_{i}}\right]^{\frac{1}{1-\eta_{i}}} Q_{i}
\end{aligned}
$$

...where $D_{i}$ interprets demand for domestic sales of commodity i; $M_{i}$ represents quantity of imported commodity i; $Q_{i}$ interprets the composite commodity i. $\gamma_{i}$ stands for the scale coefficient of ACC production function; $\delta m_{i}$ and $\delta d_{i}$ are imported and domestic scales share coefficients of ACC production functions, respectively; $P Q_{i}$ is the price of composite commodity I; $P D_{i}$ and $P M_{i}$ are the imported price of commodity $\mathrm{i}$ and the domestic sales price of commodity i, respectively; $\tau_{i}^{m}$ is the customs duty rate of commodity $\mathrm{I} ; \eta_{i}$ is

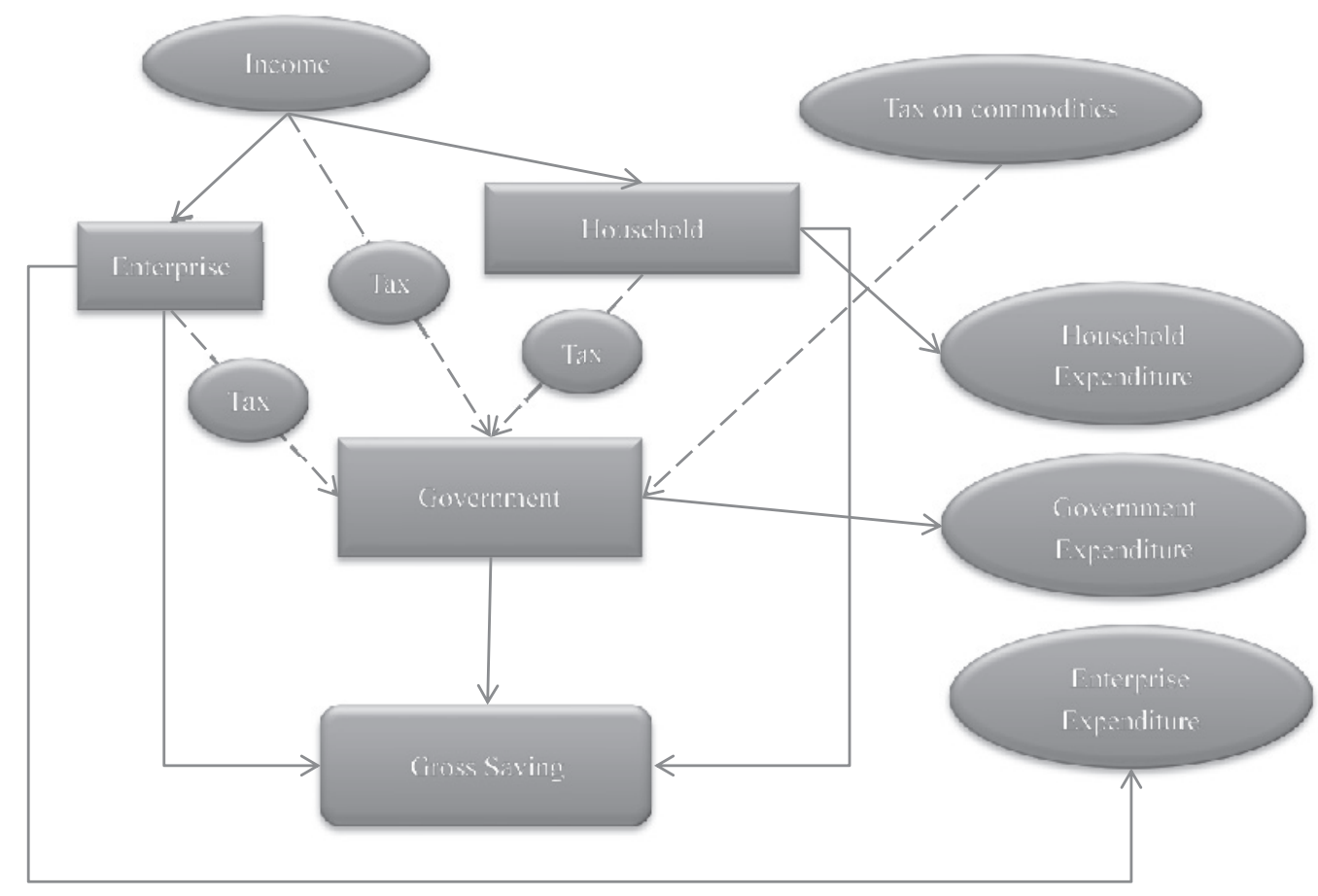

Fig. 4. Income-expenditure block framework 
the substitution parameter depended on substitution elasticity $\sigma_{i}\left(\eta_{i}=\left(\sigma_{i}-1\right) / \sigma_{i}, \eta_{i} \leq 1\right) ;$ and $\sigma_{i}$ is the substitution elasticity of imported commodity and domestic sales commodity in ACC production function.

In consideration of the supply problem of exported commodities and domestic sales commodities, constant elasticity of transformation (CET) functions have been used to interpret this conversion process:

$$
\begin{gathered}
E_{i}=\left[\frac{\theta_{i}^{\phi_{i}} \xi e_{i}\left(1+\tau_{i}^{z}\right) P Z_{i}}{P E_{i}}\right]^{\frac{1}{1-\phi_{i}}} Z_{i} \\
D_{i}=\left[\frac{\theta_{i}^{\phi_{i}} \xi d_{i}\left(1+\tau_{i}^{z}\right) P Z_{i}}{P D_{i}}\right]^{\frac{1}{1-\phi_{i}}} Z_{i}
\end{gathered}
$$

...where $E_{i}$ is the quantity of exported commodity $\mathrm{i}$; $\xi e_{i}$ and $\xi d_{i}$ are exported and domestic scales share coefficients of ACC production function, respectively; $Z_{i}$ represents the quantity of domestically produced commodity i; $P E_{i}$ is the exported price of commodity $\mathrm{i} ; P Z_{i}$ is the domestic production price of commodity $\mathrm{i} ; \tau_{i}^{\mathrm{z}}$ interprets the rate of added-value tax; $\theta_{i}$ is the scale coefficient of the i-th commodity conversion function; $\phi_{i}$ is the substitution parameter depended on substitution elasticity $\psi_{i}\left(\phi_{i}=\left(\psi_{i}+1\right) / \psi_{i}, \psi_{i} \geq 1\right)$; and $\psi_{i}$ is the substitution elasticity of exported commodity and domestic sales commodity in ACC production function.

As for the international market block, two types of commodity pricing have been considered: one is domestic price (CNY) $P_{i}^{e}$ and $P_{i}^{m}$ settled in domestic currency; the other is international price settled in international currency (USD) $P_{i}^{w e}$ and $P_{i}^{w m}$. The international market block is shown as the following functions:

$$
\begin{aligned}
& P_{i}^{e}=\mathcal{E} * P_{i}^{w e} \\
& P_{i}^{m}=\mathcal{E} * P_{i}^{w m}
\end{aligned}
$$

...where $P_{i}^{\text {we }}$ and $P_{i}^{w m}$ stand for the international export and import price of commodity i, respectively; $P_{i}^{e}$ and $P_{i}^{m}$ stand for the domestic export and import price of commodity $\mathrm{i}$; and $\varepsilon$ stand for the exchange rate of CNY against USD in 2010. At the same time, we suppose that there is a balance of payments constraint:

$$
\sum_{i} P_{i}^{w e} * E_{i}+s_{f}=\sum_{i} P_{i}^{w m} * M_{i}
$$

...where $s_{f}$ represents foreign exchange savings the same as the current account balances, which is considered an exogenous variable.

\section{Macroeconomic Closure Block}

The CGE model in this study includes three macroeconomic balances: (i) the government balance, (ii) the external balance, and (iii) the savings-investment balance. For the government balance, the closure is that all tax rates are fixed while government saving is flexible. For the external balance, which is expressed in foreign currency, the closure is that the real exchange rate is flexible residual while foreign savings is fixed. Given that the foreign saving and current account deficit are fixed in the external balance, the trade balance is also fixed. For the savingsinvestment balance, this model follows the principle of neoclassical closure, and assumes that all the savings are transformed into investment and the total investment equals total savings endogenously, thus the model is saving-driving.

\section{Energy Subsidy Policy Block}

In order to analyze the changes brought by energy de-subsidization policy, energy subsidy is set as an exogenous variable in the CGE model. Moreover, the scale of energy subsidy during 2010-2030 is exogenously based on energy consumption. The energy subsidies come from the central government financial incomes, which is determined by last year's situation of energy consumption. Precisely, there is a delay in the payment of the energy subsidy. The targets of energy subsidies are two-fold: production activity and residential consumption. Accordingly, energy subsidy is widely used to lowering the cost to energy consumers and improve the consumption of energy production [40]. It should be noted that the energy subsidies for the household are regarded as a transfer payment from the government, which has raised household incomes.

When the energy subsidies are reduced, the capital saved by reduction policy would be transferred to increase the government savings and expenditure, while the household income will decrease and the cost of production activity will increase. Then the increased government expenditure will lead to extra domestic consumption. Moreover, the increased government savings will also increase the social investment. We abstract the behavior of savings as a virtual subject, which takes all the savings in the economic system and then uses it to buy all kinds of commodities with fixed proportion shares. Generally, the energy subsidy determined by last year's energy consumption has directly affected the current year's operation of economic system and the social investment in the current year. An overview of this structure is shown in Fig. 5. 


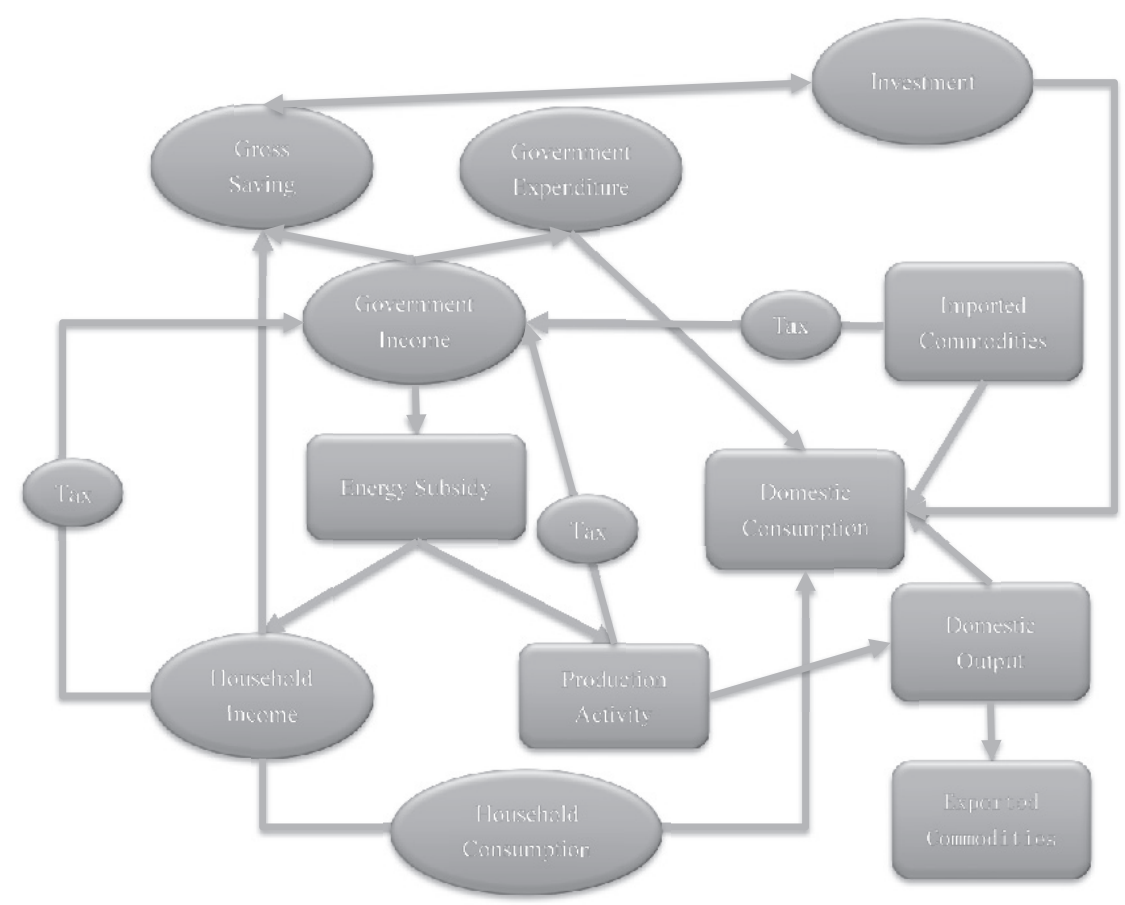

Fig. 5. Energy subsidy policy structure in the CGE model.

\section{Material}

\section{Social Accounting Matrix}

The social accounting matrix (SAM) is used mainly to describe the relationship among supply, flow of funds, and balance of each account in social national accounting, which is a comprehensive, economywide data framework. The SAM is a square matrix in which each account is represented by a row and a column. Each cell in SAM shows the payment from the account of its column to the account of its row, which is shown in Table 4 . To realistically simulate the running of environmental and economic systems, the data, which is adopted in this SAM table, comes from the China Statistical Yearbook [41], China Input-Output Association [42], China Energy Statistical Yearbook [43], China Finance Yearbook [44], and China Electric Power Yearbook [45].

\section{CGE Model Dynamics}

1) Capital. This energy de-subsidization policy CGE model can be categorized as a recursive dynamic model. The capital stock is determined by the previous year's capital stock, investment, and capital depreciation, which is fixed to each activity exogenously. In this framework, the capital stock is calculated except for the base year (2010). The base year capital stock and the capital depreciation rate is prepared and calculated by using the CSY.

2) Labor. Depended on Walras' Law, the mathematically equivalent proposition that when considering any particular market, if all other markets in an economy are in equilibrium, then that specific market must also be in equilibrium [46]. In this model, the price of labor is fixed on a constant price (value $=1$ ), while the prices of any other commodities represent a relative price level based on the price of labor. Therefore,

Table 4. Description of activities classification.

\begin{tabular}{|c|c|}
\hline Activities & Description \\
\hline AGR & $\begin{array}{c}\text { Agriculture, forestry, animal husbandry and } \\
\text { fishery }\end{array}$ \\
\hline $\begin{array}{c}\text { MIN } \\
\text { P_N }\end{array}$ & $\begin{array}{c}\text { Coal mining industry } \\
\text { Gas and oil mining industry }\end{array}$ \\
\hline OMN & Mineral mining and Other quarrying \\
\hline FPR & $\begin{array}{c}\text { Light industry includes food products and } \\
\text { agricultural products manufactory }\end{array}$ \\
\hline PPP & $\begin{array}{c}\text { Paper, Paper products and Pulp industry } \\
\text { Petroleum and coal refinery industry }\end{array}$ \\
\hline P_C & $\begin{array}{c}\text { Chemical, Plastic and Rubber products } \\
\text { CRP }\end{array}$ \\
\hline BMS & Building materials supply \\
\hline NMM & Nonferrous metal, metal and metal product \\
\hline MCH & Machinery and machinery equipment \\
\hline ELC & production and supply of electric \\
\hline GDT & Gas manufactory distribution \\
\hline CNS & Construction industry \\
\hline TRA & Transportation industry \\
\hline CSS & Community , and Services industry \\
\hline
\end{tabular}


Table 5. Growth rate of population during 2010-2030.

\begin{tabular}{|c|c|}
\hline Year & Population growth rate \\
\hline $2011-2015$ & $0.61 \%$ \\
\hline $2016-2020$ & $0.61 \%$ \\
\hline $2021-2025$ & $0.14 \%$ \\
\hline $2026-2030$ & $0.12 \%$ \\
\hline
\end{tabular}

the assumption of labor market clearing is adopted in the CGE model. Growth rate of labor supply is settled as an exogenous parameter determined by a Research Report on National Population Development Strategy [47], listed in Table 5.

3) Total factor productivity (TFP) is a variable that accounts for effects in total output growth relative to the growth in traditionally measured inputs of labor and capital. Due to simulate and estimate the future scenarios using this CGE model, the growth rate of TFP is adopted as the rate of technical progress. Dong and Zhu (2013) [48] calculated the growth rate of TFP in China during 2003-2010 based on growth accounting by panel data of 2-digit code industry. In this paper, we use the same value of the growth rate of TFP in order to simulate the future scenarios. According to mediumand long-term energy saving special planning [31], we assumed that the energy consumption level of high energy consuming sector in China is close to or reached the advanced level in the world in 2020.

\section{Scenarios}

In this CGE model, 15 scenarios are established depended on the differences in the reduction process of energy subsidies, which are listed in Tables 6 and 7.

In this study, two assumptions have been applied in order to estimate and simulate the probable scape of energy subsidy that every type of energy subsidy has been exogenously fixed based on its energy consumption

Table 6. Different energy subsidy reduction target scenarios in CGE model.

\begin{tabular}{|c|c|}
\hline \multirow{2}{*}{ Scenarios } & Reduction Process ${ }^{\text {a }}$ by Period \\
\cline { 2 - 2 } & $2011-2030$ \\
\hline BAU & $0 \%$ \\
\hline S1 & $10 \%$ \\
\hline S2 & $30 \%$ \\
\hline S3 & $50 \%$ \\
\hline S4 & $70 \%$ \\
\hline S5 & $90 \%$ \\
\hline
\end{tabular}

a Reduction process in Table 6 was a reduction percentage of energy subsidy in 2010 .
Table 7. Different mitigation routes and reform period scenarios in CGE model.

\begin{tabular}{|c|c|c|c|c|}
\hline \multirow{2}{*}{$\begin{array}{c}\text { Sce- } \\
\text { narios }\end{array}$} & \multicolumn{4}{|c|}{ Reduction Process ${ }^{\text {a }}$ by Period } \\
\cline { 2 - 5 } & $2011-2015$ & $2016-2020$ & $2021-2025$ & $2026-2030$ \\
\hline $\mathrm{T} 1$ & $15 \%$ & $20 \%$ & $25 \%$ & $30 \%$ \\
\hline $\mathrm{T} 2$ & $15 \%$ & $20 \%$ & $30 \%$ & $25 \%$ \\
\hline $\mathrm{T} 3$ & $15 \%$ & $25 \%$ & $20 \%$ & $30 \%$ \\
\hline $\mathrm{T} 4$ & $15 \%$ & $25 \%$ & $30 \%$ & $20 \%$ \\
\hline $\mathrm{T} 5$ & $15 \%$ & $30 \%$ & $20 \%$ & $25 \%$ \\
\hline $\mathrm{T} 6$ & $15 \%$ & $30 \%$ & $25 \%$ & $20 \%$ \\
\hline O1 & $0 \%$ & $\begin{array}{c}100 \% \\
(\text { in } 2020)\end{array}$ & $\begin{array}{c}100 \% \\
\text { (in } 2025)\end{array}$ \\
\hline O2 & $0 \%$ & $0 \%$ & $0 \%$ & $100 \%$ \\
\hline O3 & $0 \%$ & $0 \%$ & (in 2030$)$ \\
\hline
\end{tabular}

${ }^{\text {a }}$ Reduction process in Table 7 was a reduction percentage of energy subsidy in 2010.

calculated by standard coal; and the exogenous share coefficient is also fixed as the standard in 2010. The reason is that the Chinese government carried out many profound and crucial energy policies before 2010, such as the interventions on the contract price of thermal coal (2005), the pricing and tax reforms on oil products (2009), and the multistep residential tariff pricing reform on electricity (2010). Therefore, 2010 can be regarded as the first year after relatively large-scale energy reforms in China. In consideration of this and the correspondence of SAM data, the energy subsidy in 2010 could be considered to be a representative and reasonable choice to study the effect of energy de-subsidization policy. S1-S5 scenarios in Table 6 are constructed based on an even reduction of different de-subsidization policy targets during 2010-2030. T1-T6 scenarios have been used to explore whether the differences of different mitigation routes exist under

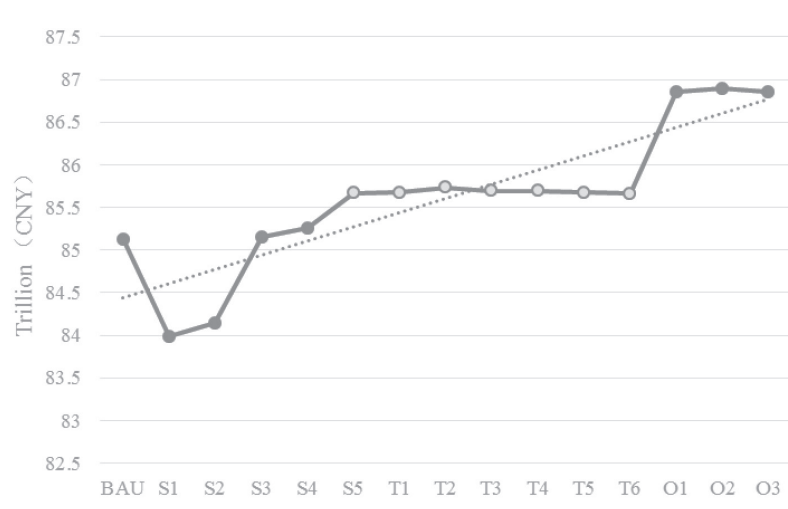

Fig. 6. All scenarios GDP in 2030 (note: the dotted line stands the trend line of GDP). 
a same energy de-subsidization target ( $90 \%$ removal) during 2010-2030. O1, O2, and O3 scenarios have shown that the total removal of energy subsidy is achieved in one year without any energy policy reduction transition, such as in 2020, 2025, and 2030, respectively.

\section{Results and Discussion}

\section{Variation of GDP}

Based on the price-gap approach and CGE model, the estimated scale of GDP (in 2010 constant price) under different scenarios is shown in Fig. 6. It should be noted that the scale of GDP in 2010 is 42.18 trillion CNY as calculated by the CGE model, which is regarded as a constant value to each scenario. The value of GDP in BAU scenario will reach 85.12 trillion CNY in 2030 . GDP in S1 and S2 scenarios will fall to 83.99 and 84.15 trillion $\mathrm{CNY}$, which has $-1.32 \%$ and $-1.14 \%$ reduction compared with the BAU scenario. From S3 to O3, GDP will rise from $0.04 \%$ to $2.09 \%$ in 2030 , where the $\mathrm{O} 2$ scenario has a best GDP value 86.9 trillion CNY. It can be concluded that GDP shows a curve tendency from lower to higher and the yellow points in Fig. 6 imply the differences of different mitigation routes with the same small target. Apparently, the various implementations of energy de-subsidization policy do affect the development of economics in China. The reason why the energy reduction policy can cause a nonlinear trend in the development of GDP will be discussed later.

\section{Domestic Output and Consumption}

The variation on domestic output caused by energy de-subsidization policy is illustrated in Fig. 7. Due to various reduction policies, we settled on three discussion groups: group A (from scenario BAU to scenario S5 in Fig. 7a), group B (from scenario S5 to scenario T6 in Fig. 7b), and group $\mathrm{C}$ (scenario BAU and scenario $\mathrm{O} 1$ to scenario $\mathrm{O} 3$ in Fig. 7c) for better analysis. Mostly in group A, the reduction on energy subsidy has a continuously negative effect on domestic output except for the PPP and CSS. As seen in Fig. 7a), the PPP industry has a relatively stable output and the CSS industry has an opposite result with the others. With the scale of subsidy reduction, the CSS industry output increases. With the aggravated reduction on energy subsidy, the domestic output of CSS will vary from $-1.74 \%$ to $2.03 \%$. Moreover, the energy industry, such as MIN, P_N, and GDT, has been heavily affected - especially the $\mathrm{P} \_\mathrm{N}$ industry. In scenario S5, the P_N has fallen by $-13.01 \%$, which has declined most of all. It can be noted that the more energy subsidy reduces, the worse recession would exist in the primary and secondary industries. In Fig. 7b), the results have revealed that different mitigation routes of the same energy de-subsidization target only have a tiny difference on domestic output. By contrast with group $\mathrm{A}$, there is a different conclusion based on the results of group $\mathrm{C}$. The energy subsidy removal accomplished in a

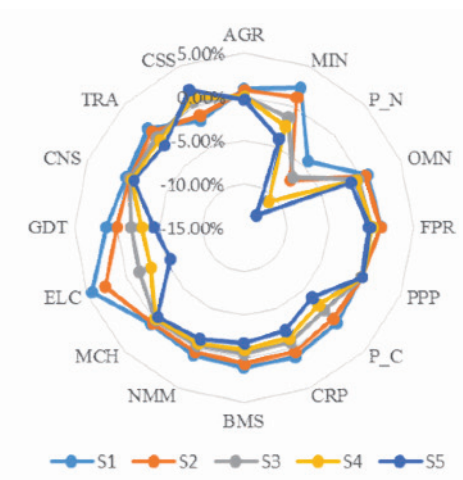

a. The domestic output variation of $\mathrm{S} 1-\mathrm{S} 5$ scenario in 2030

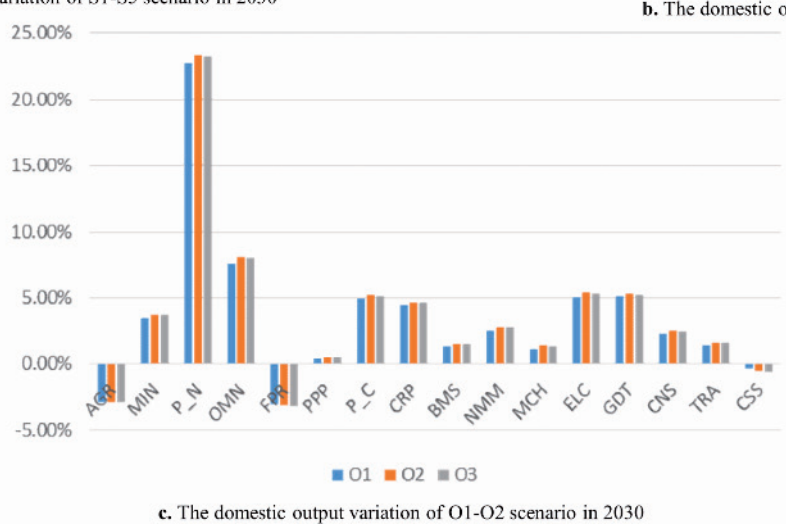

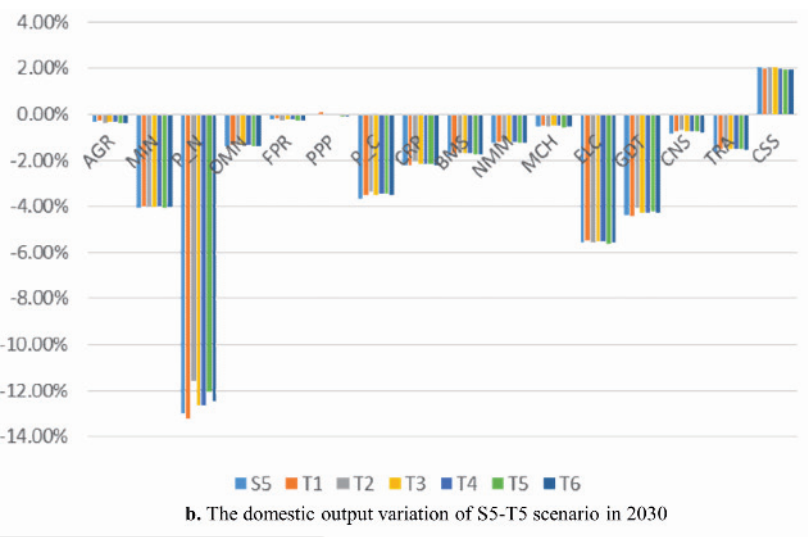

Fig. 7. Domestic output variation of different scenarios in 2030. 


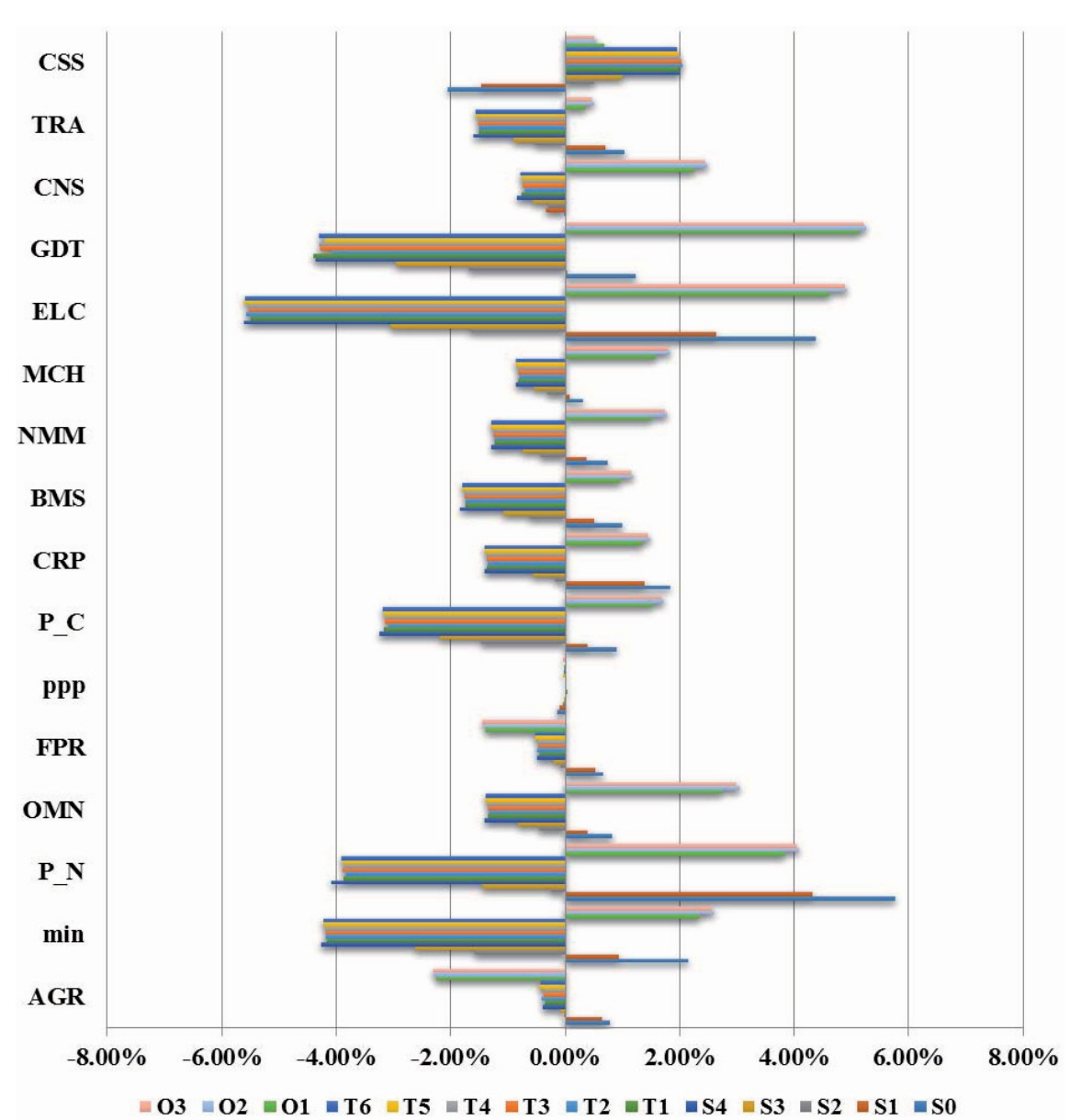

Fig. 8. Variation of domestic consumption in 2030.

year has increased most of the industrial output except for the AGR, FPR, and CSS. The P_N has increased by $23.29 \%$ in scenario O2. Other energy industries, such as MIN and GDT, and energy transformation industries such as the P_C and ELC have increased more than any other industry. It should be noted that energy desubsidization policies can also promote the output of the energy industry.

The variation of domestic consumption is shown in Fig. 8. Generally, the reduction on energy subsidy has

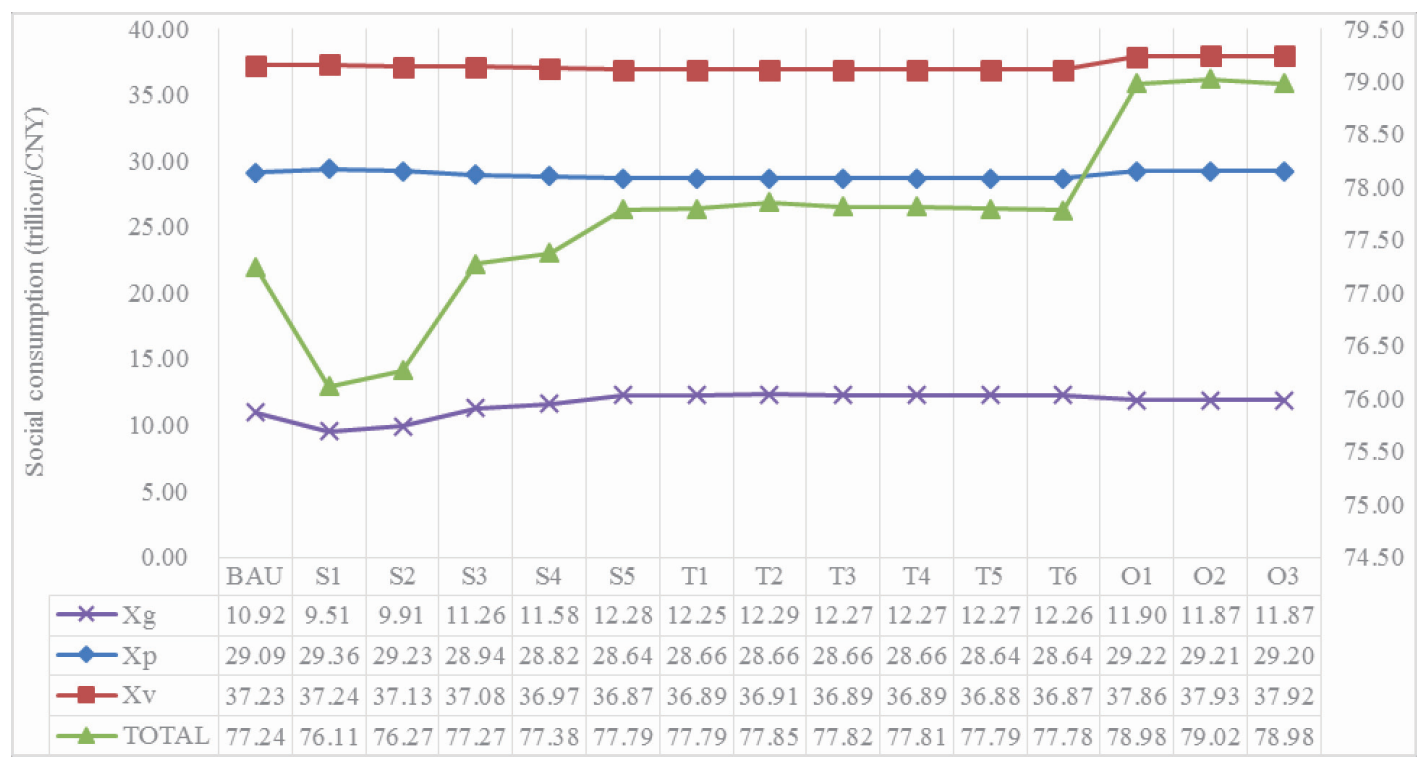

Fig. 9. Social consumption in 2030. 
Table 8. Variation of social welfare in $2030(\%)$.

\begin{tabular}{|c|c|c|c|c|c|c|c|}
\hline & $\mathrm{S} 1$ & $\mathrm{~S} 2$ & $\mathrm{~S} 3$ & $\mathrm{~S} 4$ & $\mathrm{~S} 5$ & $\mathrm{~T} 1$ & $\mathrm{~T} 2$ \\
\hline $\mathrm{EV}^{\mathrm{a}}$ & -7.36 & -8.91 & -7.77 & -8.96 & -11.64 & -13.38 & -11.01 \\
\hline & $\mathrm{T} 3$ & $\mathrm{~T} 4$ & $\mathrm{~T} 5$ & $\mathrm{~T} 6$ & $\mathrm{O} 1$ & $\mathrm{O} 2$ & $\mathrm{O} 3$ \\
\hline $\mathrm{EV}$ & -12.75 & -10.73 & -11.36 & -10.66 & 10.67 & 10.83 & 36.64 \\
\hline
\end{tabular}

${ }^{a} \mathrm{EV}$ represents the social welfare loss

a similarly negative effect on domestic consumption, especially energy industries. Nevertheless, a total removal of energy subsidy in a year will also cause a sharp increase demand of commodities, such as scenarios $\mathrm{O} 1, \mathrm{O} 2$, and $\mathrm{O} 3$. In this CGE model, all the commodities markets are cleared so that the variation of demand for domestic consumption is consistent with the variation of domestic output. Moreover, the impact of energy de-subsidization policy has also directly affected the output price and consumption price: in scenario S1-T6, most industry prices have an obvious increase; in scenario O1-O3, the price has dramatically fallen. For example, the output price of the $\mathrm{P} \_\mathrm{N}$ industry varies from $10.26 \%$ to $14.89 \%$, and in scenario O1-O3 the price has fallen by $23.34 \%$ to $23.72 \%$; the consumption price of $\mathrm{P}_{-} \mathrm{N}$ industry has increased from $5.91 \%$ to $7.85 \%$, and when in scenario O1-O3, the price has fallen by $17.21 \%$ to $17.49 \%$. This is why the $\mathrm{P}_{-} \mathrm{N}$ industry has a most remarkable influence both in output and consumption.

\section{Social Impact and Welfare}

As illustrated in 3.4, energy de-subsidization policy has a bidirectional influence on the macroeconomic system by dint of social consumption and savings. In this study, the social consumption and savings system consists of the household consumption and savings, government consumption and savings, investment, and enterprise savings. It should be noted that social consumption is different from domestic consumption because the intermediate inputs are not concluded. Due to the same source of income (factor incomes) and payment behavior, an enterprise's behavior can be combined with the household's into the public's behavior.

Social consumption structure in 2030 is illustrated in Fig. 9. The scenarios in group A have evidently showed that there is a nonlinear tendency on social consumption due to energy de-subsidization policy. In this paper, GDP is calculated according to the expenditure method, which is mainly determined by social consumption. Therefore, the results of GDP are generally consistent with social consumption. And the scale of social consumption in group B has a similar value that varies from 77.77 to 77.79 trillion CNY. Furthermore, the results also have interpreted the reason why the consumption of energy intensity industries will sharply increase in scenarios O1, O2, and O3. Since the total removal of energy subsidies is achieved in scenarios $\mathrm{O} 1, \mathrm{O} 2$, and $\mathrm{O} 3$, the $\mathrm{Xg}$ has increased by $0.45 \%, 0.44 \%$, and $0.39 \%$; the Xp has increased by $1.68 \%, 1.89 \%$, and $1.84 \%$. Besides, the scale of social consumption has reached its strongest level to 79.02 trillion $\mathrm{CNY}$ in scenario $\mathrm{O} 2$, while $\mathrm{O} 1$ and $\mathrm{O} 3$ have reached 78.98 and 78.99 trillion CNY, respectively. The increased social consumption has caused the variation of domestic consumption and output due to resident utility maximization based on income constraints.

In this CGE model, with the help of the Laspeyres price index method, as shown in equation (7), we transfer the utility level into an expenditure level in order to set up a social welfare index, which is defined as Hicksian equivalent variation $(\mathrm{EV})$ :

$$
\mathrm{EV}=\operatorname{ep}\left(P^{q 0}, U U^{1}\right)-e p\left(P^{q 0}, U U^{0}\right)
$$

...where $\operatorname{ep}(*)$ represents the expenditure function; UU0 represents the social welfare level in basic year and UU1 represents the social welfare level in current year; and $\mathrm{Pq} 0$ means the price vector in a basic year. It should be noted that the value of EV itself would not have economic significance but could be used to quantify the social welfare in 2030 in all scenarios. According to Table 8 , the results have obviously shown that the social welfare loss existed more significantly, especially with the gradually radical energy de-subsidization policy achieved during 2010-2030. Relatively, under the same

Table 9. Carbon emissions in $2030(\%)$.

\begin{tabular}{|c|c|c|c|c|c|c|c|}
\hline & S1 & S2 & S3 & S4 & S5 & T1 & T2 \\
\hline 2030 & -2.11 & -3.13 & -4.43 & -7.19 & -10.16 & -7.28 & -6.41 \\
\hline & T3 & T4 & T5 & T6 & O1 & O2 & O3 \\
\hline 2030 & -9.73 & -11.03 & -7.52 & -8.09 & 14.78 & 12.84 & 13.2 \\
\hline
\end{tabular}


reduction target, the different mitigation routes also had a small impact on social welfare, where scenario T6 had better resident utility. Nevertheless, with the total removal of energy subsidy in one year, the reallocated current funds saved by the de-subsidization policy caused the opposite value of social welfare due to increasing public consumption.

\section{Carbon Emissions}

The variation of carbon emissions is shown in Table 9. In the BAU scenario, the amount of carbon emissions will reach 1.69 billion tons of $\mathrm{CO}_{2}$ in 2010 and 8.5 billion tons in 2030. Carbon emissions in group A have shown a gradual emission reduction based on the increased scopes of energy de-subsidization. In scenario $\mathrm{S} 5$, carbon emission reaches a least emission levels to 7.64 billion tons of $\mathrm{CO}_{2}$ in 2030. In consideration of group $\mathrm{B}$, scenario $\mathrm{T} 4$ has better performance and reduced 0.94 billion tons of $\mathrm{CO}_{2}$ compared with the BAU scenario. The other scenarios in group B have a similar scale of carbon emissions that varied from 7.81 to 7.96 billion tons of $\mathrm{CO}_{2}$. As discussed before, the total removal of energy subsidy in group $\mathrm{C}$ has led to an increase of domestic consumption, especially in energy-intense industries, which has aroused an excess carbon emission in 2030. Although the total removal of energy subsidies will lead to a better improvement in GDP in group $\mathrm{C}$, the carbon emissions will have a worst environmental pollution situation and would reach 9.76 billion tons of $\mathrm{CO}_{2}$ in scenario $\mathrm{O} 1$ and 9.39 and 9.68 billion tons of $\mathrm{CO}_{2}$, respectively, in scenarios $\mathrm{O} 2$ and $\mathrm{O} 3$.

\section{Conclusions}

As discussed previously, the results in group A have shown that there could be a nonlinear tendency of macroeconomic development in 2030. GDP shows a tendency from lower to rise, which reaches a lower point in scenario $\mathrm{S} 1$ and then rises to 85.67 trillion $\mathrm{CNY}$ in scenario S5. Moreover, the nonlinear tendency in GDP is consistent with the tendency in social consumption and domestic output.

Then, different ways to implement the energy desubsidization policy have an obvious difference. When the target of energy de-subsidization policy becomes more and more radical, the development of economics shows a gradually deteriorative trend. However, different mitigation routes with the same subsidy reduction target have a similar impact on the final results of economics during 2010-2030. It can be concluded that if the subsidy reduction target is fixed, what the mitigation route is would not be the crucial influence during the certain reform period. Moreover, a total removal of energy subsidy like scenario O1-O3 could receive an opposite result. The energy subsidy capital saved by the energy de-subsidization policy would have been more inclined to promote the development of economics and increase the domestic consumption and output. That is to say, the positive effects would be the main impact instead of the coexistence of bidirectional influences.

The results of social welfare also imply a similar conclusion. Moreover, the capital saved by the different de-subsidization policies play a significant role in macroeconomic impact. If the energy de-subsidization policy achieved in one year such as scenarios O1, O2, and $\mathrm{O} 3$, the saved funds can lead to a sharp increase in economics; if the funds were evenly reallocated in 20 years - such as in scenarios S1 to S5 - the negative effects would be more obvious.

Even though there is better economic performance in scenarios $\mathrm{O} 1, \mathrm{O} 2$, and $\mathrm{O} 3$, more energy consumption and carbon emissions made the total removal of energy subsidies not practically significant. Generally, any other de-subsidization policy in stages may result in the economic slowdown and social welfare loss in each scenario. Based on our results, a medium desubsidization target (50\%-90\%) with an average reduction during 2010-2030 could be a suitable and constructive suggestion for the Chinese government. According to the economic slowdown and social welfare loss in each scenario, the incentive economic policy like lowering tax rate would be better along with the energy de-subsidization policy.

This paper also offers further possibilities for future work. In this paper, the price-gap approach and CGE model are combined and applied to simulate the possible de-subsidization policy in China, which means some other models, such as producer subsidy equivalent (PSE) and program-specific approach are not considered. Moreover, the energy subsidy structure can be built under other reasonable assumptions. And the simulation of possible de-subsidization policy may not be representative enough. The economic and energy regulatory [49] and the public-private partnerships in the energy sector also could be considered in future work. Finally, there may be some other social factors not considered in the CGE model, such as the classification of residents, the poverty gap, and the regional developmental balance.

\section{Acknowledgments}

This study is supported by the National Social Science Foundation of China (grant No. 15BGL145), the National Natural Science Foundation of China (grant No. 71471061), the Foundation Research Funds for the Central Universities (No. 2016MS125), and the Philosophy and Social Science Research Base of Hebei Province.

\section{Conflict of Interest}

The authors declare no conflict of interest. 
Appendix: Equation system of the recursive CGE model

\begin{tabular}{|c|c|}
\hline$V A E_{i}=\alpha_{i}^{v a e}\left[\delta_{i}^{v a e} V A_{i}^{\rho_{i}^{v a e}}+\left(1-\delta_{i}^{v a e}\right) E N E_{i}^{\rho_{i}^{v a e}}\right]^{1 / \rho_{i}^{v a e}}$ & (A.1) \\
\hline$\frac{P V A_{i}}{P E N E_{i}}=\frac{\delta_{i}^{\text {vae }}}{1-\delta_{i}^{v a e}}\left(\frac{E N E_{i}}{V A_{i}}\right)^{1-\rho_{i}^{v a e}}$ & (A.2) \\
\hline$P V A E_{i} \cdot V A E_{i}=P V A_{i} \cdot V A_{i}+P E N E_{i} \cdot E N E_{i}$ & (A.3) \\
\hline$V A_{i}=\alpha_{i}^{v a}\left[\delta_{i}^{v a} L A B_{i}^{\rho_{i}^{v a}}+\left(1-\delta_{i}^{v a}\right) C A P_{i}^{\rho_{i}^{v a}}\right]^{1 / \rho_{i}^{v a}}$ & (A.4) \\
\hline$\frac{P L A B_{i}}{P C A P_{i}}=\frac{\delta_{i}^{v a}}{1-\delta_{i}^{v a}}\left(\frac{C A P_{i}}{L A B_{i}}\right)^{1-\rho_{i}^{v a}}$ & (A.5) \\
\hline$P V A_{i} \cdot V A_{i}=P L A B_{i} \cdot L A B_{i}+P C A P_{i} \cdot C A P_{i}$ & (A.6) \\
\hline$E N E_{i}=\alpha_{i}^{\text {ene }}\left[\delta_{i}^{\text {ene }} O I L_{i}^{\rho_{i}^{\text {ene }}}+\left(1-\delta_{i}^{\text {ene }}\right) N O I L_{i}^{\rho_{i}^{\text {ene }}}\right]^{1 / \rho_{i}^{\text {ene }}}$ & (A.7) \\
\hline$\frac{\mathrm{POIL}_{i}}{P N O I L_{i}}=\frac{\delta_{i}^{\text {ene }}}{1-\delta_{i}^{\text {ene }}}\left(\frac{N O I L_{i}}{O I L_{i}}\right)^{1-\rho_{i}^{\text {ene }}}$ & (A.8) \\
\hline PENE $_{i} \cdot$ ENE $_{i}=$ POIL $_{i} \cdot$ OIL $_{i}+$ PNOIL $_{i} \cdot$ NOIL $_{i}$ & (A.9) \\
\hline $\operatorname{NOIL}_{i}=\alpha_{i}^{\text {noe }}\left[\delta_{i}^{\text {noe }} \operatorname{COAL}_{i}^{\rho_{i}^{\text {noe }}}+\left(1-\delta_{i}^{n o e}\right) \operatorname{NOS}_{i}^{\rho_{i}^{\text {noe }}}\right]^{1 / \rho_{i}^{\text {noe }}}$ & (A.10) \\
\hline$\frac{P C O A L_{i}}{P N O S_{i}}=\frac{\delta_{i}^{n o e}}{1-\delta_{i}^{n o e}}\left(\frac{N O S_{i}}{C O A L_{i}}\right)^{1-\rho_{i}^{\text {noe }}}$ & (A.11) \\
\hline PNOIL $_{i} \cdot$ NOIL $_{i}=$ PCOAL $_{i} \cdot$ COAL $_{i}+\operatorname{PNOS}_{i} \cdot$ NOS $_{i}$ & (A.12) \\
\hline$N O S_{i}=\alpha_{i}^{n o s}\left[\delta_{i}^{n o s} E L E_{i}^{\rho_{i}^{n o s}}+\left(1-\delta_{i}^{n o s}\right) G A S_{i}^{\rho_{i}^{n o s}}\right]^{1 / \rho_{i}^{n o s}}$ & (A.13) \\
\hline$\frac{P E L E_{i}}{P G A S_{i}}=\frac{\delta_{i}^{n o s}}{1-\delta_{i}^{n o s}}\left(\frac{G A S_{i}}{E L E_{i}}\right)^{1-\rho_{i}^{\text {nos }}}$ & (A.14) \\
\hline$P N O S_{i} \cdot N O S_{i}=P E L E_{i} \cdot E L E_{i}+P G A S_{i} \cdot G A S_{i}$ & (A.15) \\
\hline$O I L_{i}=\alpha_{i}^{o i l}\left[\delta_{i}^{o i l 1} \operatorname{GASOLINE~}_{i}^{\rho_{i}^{o i l}}+\delta_{i}^{\text {oil } 2} \operatorname{DIESEL}_{i}^{\rho_{i}^{o i l}}+\left(1-\delta_{i}^{\text {oil } 1}-\delta_{i}^{o i l 2}\right) \mathrm{FUEL}_{i}^{\rho_{i}^{o i l}}\right]^{1 / \rho_{i}^{o i l}}$ & (A.16) \\
\hline$\frac{\text { PGASOLINE }_{i}}{\text { PDIESEL }_{i}}=\frac{\delta_{i}^{\text {oil }}}{\delta_{i}^{\text {oil } 2}}\left(\frac{\text { DIESEL }_{i}}{\text { GAOSOLINE }_{i}}\right)^{1-\rho_{i}^{o i l}}$ & (A.17) \\
\hline
\end{tabular}




\begin{tabular}{|c|c|}
\hline$\frac{\text { PGASOLINE }_{i}}{\text { PFUEL }_{i}}=\frac{\delta_{i}^{o i l 1}}{1-\delta_{i}^{o i l 1}-\delta_{i}^{o i l 2}}\left(\frac{F U E L_{i}}{G A O S O L I N E_{i}}\right)^{1-\rho_{i}^{o i l}}$ & (A.18) \\
\hline POIL $_{i} \cdot$ OIL $_{i}=$ PGASOLINE $_{i} \cdot$ GASOLINE $_{i}+$ PDIESEL $_{i} \cdot$ DIESEL $_{i}+$ PFUEL $_{i} \cdot$ FUEL $_{i}$ & (A.19) \\
\hline$I N T_{i, j}=a_{i, j}^{I N T} Z_{j}$ & (A.20) \\
\hline$V A E_{j}=a_{j}^{V A E} Z_{j}$ & (A.21) \\
\hline$P Z_{j}=a_{j}^{\text {vae }} P V A E+\sum_{i} a_{i, j}^{I N T} P Q_{i}$ & (A.22) \\
\hline$T D=\tau^{d} \sum_{i}\left(P C A P_{i} \cdot C A P_{i}+P L A B_{i} \cdot L A B_{i}+\right.$ subsidy_h $)$ & (A.23) \\
\hline$T Z_{i}=\tau^{z} P Z_{i} Z_{i}$ & (A.24) \\
\hline$T M_{i}=\tau^{m} P M_{i} M_{i}$ & (A.25) \\
\hline$X V_{i}=\frac{\lambda_{i}}{P Q_{i}}(S P+S G+\varepsilon S F)$ & (A.26) \\
\hline$S P=s s^{p} \sum\left(P C A P_{i} \cdot C A P_{i}+P L A B_{i} \cdot L A B_{i}+s u b s i d y_{-} h\right)$ & (A.27) \\
\hline$S G=s s^{g}\left(T D+\sum_{i} T Z_{i}+\sum_{i} T M_{i}-s u b s i d y_{-} t\right)$ & (A.28) \\
\hline$X G_{i}=\frac{\mu_{i}}{P Q_{i}}\left(T D+\sum_{i} T Z_{i}+\sum_{i} T M_{i}-\right.$ subsidy_t $\left.t-S G\right)$ & (A.29) \\
\hline$X P_{i}=\frac{\beta_{i}^{x p}}{P Q_{i}}\left(\sum_{i}\left(P C A P \cdot C A P_{i}+P L A B \cdot L A B_{i}+\right.\right.$ subsidy_h $\left.\left.h\right)-S P-T D\right)$ & (A.30) \\
\hline$P E_{i}=\varepsilon P W E_{i}$ & (A.31) \\
\hline$P M_{i}=\varepsilon P W M_{i}$ & (A.32) \\
\hline$\sum_{i} P W E_{i} E_{i}+S F=\sum_{i} P W M_{i} M_{i}$ & (A.33) \\
\hline$Q_{i}=\gamma_{i}\left(\delta m_{i} M_{i}^{\eta_{i}}+\delta d_{i} D_{i}^{\eta_{i}}\right)^{1 / \eta_{i}}$ & (A.34) \\
\hline$M_{i}=\left[\frac{\gamma_{i}^{\eta_{i}} \delta m_{i} P Q_{i}}{\left(1+\tau_{i}^{m}\right) P M_{i}}\right]^{\frac{1}{1-\eta_{i}}} Q_{i}$ & (A.35) \\
\hline
\end{tabular}




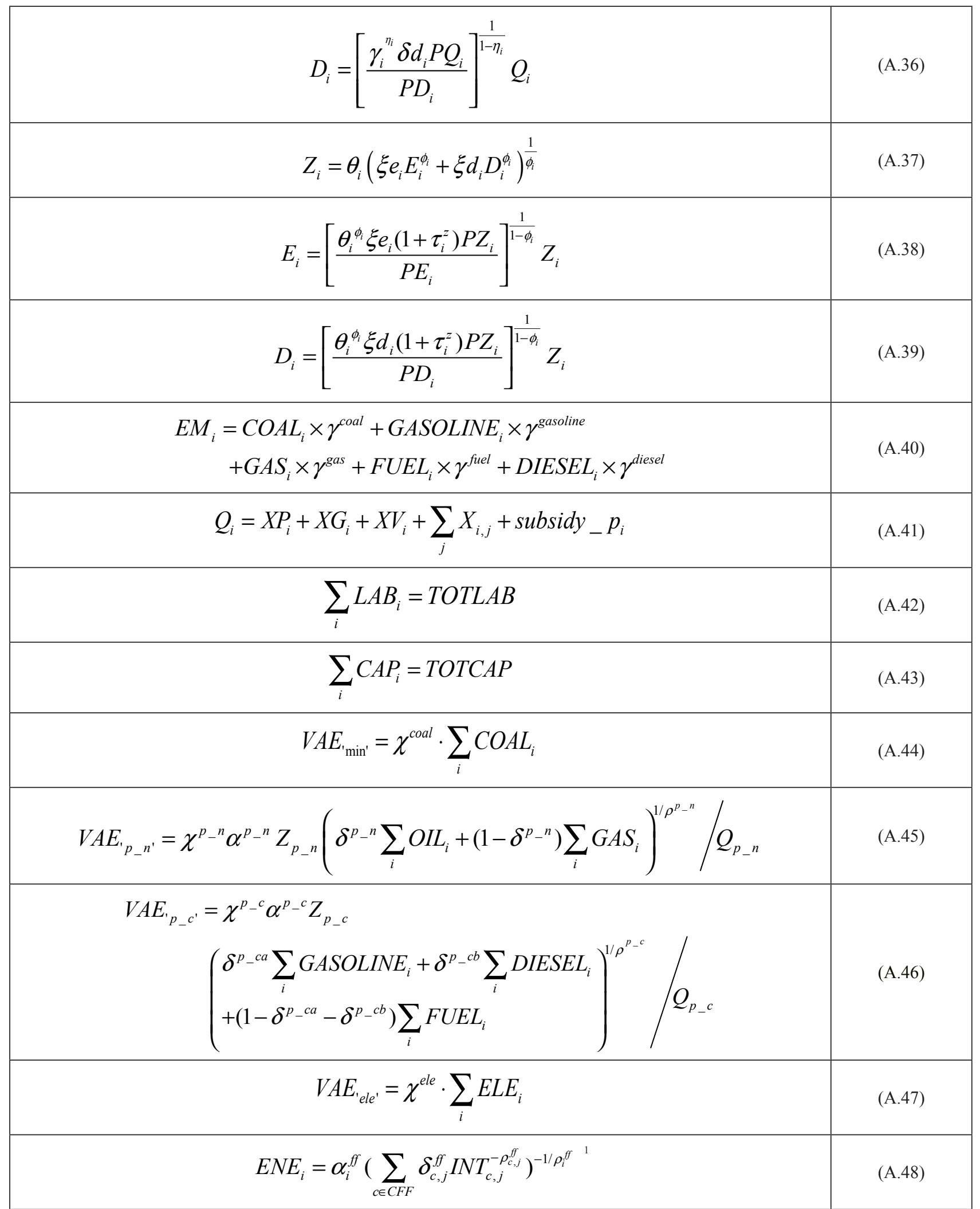


Equation (A.1) to Equation (A.21) represent the production block of the CGE model, which is discussed in section 3.1. $V A E_{i}$ represents the energy and valueadded (VAE) bundle; $V A_{i}$ represents the value-added bundle; $E N E_{i}$ represents the energy bundle; $P V A_{i}$, $P E N E_{i}$, and $P V A E_{i}$ represent the price of $V A_{i}, E N E_{i}$ and $V A E_{i} ; L A B_{i}$ and $C A P_{i}$ represent the quantity of labor and capital needed in production; $O I L_{i}$ represents the quantity of the petroleum fuel needed in production; $N O I L_{i}$ represents the quantity of non-petroleum fuel needed in production; $C O A L_{i}$ represents the quantity of the coal fuel needed in production; NOS represents the quantity of non-coal fuels needed in production; $E L E_{i}$ represents the quantity of electricity needed in production; $G A S_{i}$ represents the quantity of natural

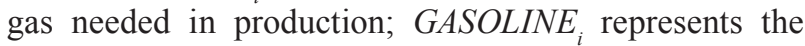
quantity of gasoline needed in production; $D I S E L_{i}$ represents the quantity of diesel oil needed in production; $F U E L_{i}$ represents the quantity of fuel oil needed in production; $I N T_{i, j}$ represents the quantity of intermediate input; and PLAB , PCAP $_{i}$, POIL, PNOIL, PCOAL PNOS , PELE $_{i}$ PGAS , PGASOLINE, PDIESEL $_{i}$ and $P F U E L_{i}$ represent the price of $L A B_{i}, C A P_{i}, O_{i}, N O I L_{i}$, COAL $L_{i}$ NOS $_{i}, E_{i} E_{i}, G A S_{i}, G A S O L I N E_{i}$, DIESEL $_{i}$ and FUEL.

Equation (A.22) to Equation (A.26) represent the Income-expenditure block of the CGE model, which is discussed in section 3.2; TD represents direct taxes; $T D_{i}$ represents the taxes on production; $T M_{i}$ represents import taxes; $X V_{i}$ represents the quantity of investment; $S P$ represents the quantity of personal savings; and $S G$ represents the quantity of government savings.

Equation (A.27) to Equation (A.39) represents the market block of the CGE model, which is discussed in section 3.3. Equation (A.40) represents the carbon emissions of the CGE model.

Equation (A.41) to Equation (A.43) represent the macroeconomic closure block of the CGE model, which is discussed in section 3.4; TOTLAB represents the total quantity of labors and TOTCAP represents the total quantity of capital.

Equation (A.44) to Equation (A.48) represent the constraint condition of the CGE model. And the Energy subsidy policy block is represented through Equation (A.23), Equation (A.27) to Equation (A.30), and Equation (A.41).

\section{References}

1. MARTINS A.C., MARQUES R.C., CRUZ C.O. Publicprivate partnerships for wind power generation: The Portuguese case. Energy Policy, 39 (1), 94, 2011.

2. IEA. World Energy Outlook 2010. International Energy Agency, Paris, France, 2010.

3. SOILE I.O., TSAKU H., MUSA B. The Impact of Gasoline Subsidy Removal on the Transportation Sector in Nigeria. American Journal of Energy Research, 2 (3), 60, 2014.

4. WESSEH P.K., LIN B.Q., ATSAGLI P. Environmental and welfare assessment of fossil-fuels subsidies removal:
A computable general equilibrium analysis for Ghana. Energy, 116, 1172, 2016.

5. LIN B.Q., JIANG Z.J., LIN J. Targeted electricity tariff subsidy is conductive to equity and efficiency. Journal of Financial Research, 11, 1, 2009 [In Chinese].

6. GSI. The Effects of Fossil-Fuel Subsidy Reform: A Review of Modelling and Empirical Studies. International Institute for Sustainable Development. Global Subsidy Initiative, Geneva, Switzerland, 2010. Available online: http://www.proshareng.com/admin/upload/reports/ FuelSubsidiTheiImpactandPathtoReform.pdf.(accessed on 25 October 2016)

7. MICHELLE S. Fossil fuel reform in developing states: The case of Trinidad and Tobago, a petroleum producing small Island developing State. Energy Policy, 104, 265, 2017.

8. DUBE I. Impact of energy subsidies on energy consumption and supply in Zimbabwe. Do the urban poor really benefit? Energy Policy, 31 (15), 1635, 2003.

9. UNEP. Reforming Energy Subsidies: Opportunities to Contribute to the Climate Change. United Nations Environment Programme: Nairobi, the Republic of Kenya, 2008.

10. World Bank. Climate Change and the World Bank Group Phase 1 - An Evaluation of World Bank Win-Win Energy Policy Reforms. World Bank: Washington DC, U.S, 2009.

11. RAO N.D. Kerosene subsidies in India: When energy policy fails as social policy. Energy for Sustainable Development, 16 (1), 35, 2012.

12. MOOR A.D. Towards a grand deal on subsidies and climate change. Natural Resources Forum, 25 (2), 167, 2001.

13. TARR D.G., JENSEN J. Trade, Foreign Exchange, and Energy Policies in the Islamic Republic of Iran: Reform Agenda, Economic Implications, and Impact on the Poor. World Bank Policy Research Working Paper, 2768, 1, 2002.

14. ACHARYA R.H., SADATH A.C. Implications of energy subsidy reform in India. Energy Policy, 102, 453, 2017.

15. COADY D., NEWHOUSE D. Evaluating the Fiscal and Social Costs of Increases in Domestic Fuel Prices, in: Poverty and social analysis of reforms: lessons and examples from implementation. International Monetary Fund - Washington DC, U.S., 387, 2006.

16. BAZILIAN M., ONYEJI I. Fossil fuel subsidy removal and inadequate public power supply: Implications for businesses. Energy Policy, 45 (6), 1, 2012.

17. World Bank. Analysis of the Scope of Energy Subsidies and Suggestions for the G-20 Initiative. The Impact of Energy Subsidies Removal on the Poor. The G-20 Summit Meeting. World Bank: Washington DC, U.S, 2010. Available online:http://www.worldenergyoutlook.org/ media/weowebsite/energysubsidies/G20_Subsidy_Joint Report.pdf. (accessed on 25 June 2016).

18. LI H. Impacts and Advices on Residents with Subsidies Reform under the Background of Low-carbon Economic in China. Issues in Agricultural Economy, 02, 89, 2011 [In Chinese].

19. LIN B.Q., LI A.J. Impacts of removing fossil fuel subsidies on China: How large and how to mitigate? Energy, 44 (1), 741, 2012.

20. NASTARAN A., ABBAS S. A system dynamics analysis of energy consumption and corrective policies in Iranian iron and steel industry. Energy, 43 (1), 334, 2012.

21. ARIAS A.D., BEERS C.V. Energy subsidies, structure of electricity prices and technological change of energy use. Energy Economics, 40 (04), 495, 2013. 
22. PLANTE M. The long-run macroeconomic impacts of fuel subsidies. Journal of Development Economics, 107 (1), 129, 2011.

23. SIDDIG K., AGUJAR A., GRETHE H., MINOR P., WALMSLEY T. Impacts of Removing Refined Oil Import Subsidies in Nigeria on Poverty. The 10th PEP Annual Meeting, 1, 2013.

24. LIN B.Q., JIANG Z.J. Estimates of energy subsidies in China and impact of energy subsidy reform. Energy Economics, 33 (2), 273, 2011.

25. LI H. Fossil Fuel Subsidies and Carbon Emission Reduction in China: Theoretical and Empirical Analysis on the scale of energy subsidies. Economic Perspectives, 03, 92, 2011 [In Chinese].

26. IEA. World Energy Outlook. Insights, Looking at Energy Subsidies: Getting the Prices Right. International Energy Agency: Paris, France, 1999.

27. LIN B.Q., OUYANG X.L. A revisit of fossil-fuel subsidies in China: Challenges and opportunities for energy price reform. Energy Conversion and Management, 82, 124, 2014.

28. LIN B.Q., JIA Z.J. The impact of Emission Trading Scheme (ETS) and the choice of coverage industry in ETS: A case study in China. Applied Energy, 205, 1512, 2017.

29. LIN B.Q., JIA Z.J. Impact of quota decline scheme of emission trading in China: A dynamic recursive CGE model. Energy, 149 (15), 190, 2018.

30. JIANG Z.J., LIN B.Q. The perverse fossil fuel subsidies in China - The scale and effects. Energy, 70 (3), 411, 2014.

31. National Development and Reform Commission (NDRC). Medium and long-term energy saving special planning [In Chinese]. Available online: http://www.ndrc.gov.cn/ fzgggz/hjbh/jnjs/200507/t20050711_45823.html. (accessed on 16 November 2016).

32. IMF. Energy Subsidy Reform: Lessons and Implications. International Monetary Fund: Washington DC, U.S, 2013.

33. OUYANG X.L., LIN B.Q. Levelized cost of electricity (LCOE) of renewable energies and required subsidies in China. Energy Policy, 70 (7), 64, 2014.

34. RIVE N., TORVANGER A., FUGLESTVEDT J.S. Climate agreements based on responsibility for global warming: Periodic updating, policy choices, and regional costs. Global Environmental Change, 16 (2), 182, 2006.

35. ARNDT C., DAVIES R., GABIREL S., MAKRELOV K., MEREN B., HARTLEY F., THURLOW J. A sequential approach to integrated energy modeling in South Africa. Applied Energy, 161, 591, 2016.

36. DAI H.C., XIE X.X., XIE Y., L J., MASUI T. Green growth: The economic impacts of large-scale renewable energy development in China. Applied Energy, 162, 435, 2016.

37. CAI Y.Y., ARORA V. Disaggregating electricity generation technologies in CGE models: A revised technology bundle approach with an application to the U.S. Clean Power Plan. Applied Energy, 154, 543, 2015.

38. LI W., JIA Z.J. The impact of emission trading scheme and the ratio of free quota: A dynamic recursive CGE model in China. Applied Energy, 174, 1, 2016.

39. LI W., JIA Z.J, ZHANG H.Z. The impact of electric vehicles and CCS in the context of emission trading scheme in China: A CGE-based analysis. Energy, 119, 800, 2017.

40. OECD. Improving the Environment through Reducing Subsidies. OECD: Paris, France, 1998.

41. National Bureau of Statistics. China Statistics Yearbook 2011 [In Chinese]. Available online: http://www.stats.gov. $\mathrm{cn} / \mathrm{tjsj} / \mathrm{ndsj} /$ (accessed on 07 September 2016).

42. China Input-Output Association. 2010 Input-Output Table [In Chinese]. Available online: http://www.iochina.org.cn/ Download/xgxz.html (accessed on 07 September 2016).

43. National Bureau of Statistics. China Energy Statistics Yearbook 2011 [In Chinese]. Available online: http://cyfd. cnki.com.cn/N2012020066.htm-accessed on 07 September 2016.

44. China financial magazine. China Finance Yearbook 2011 [In Chinese]. Available online: http://cyfd.cnki.com.cn/ N2011120152.htm (accessed on 07 September 2016).

45. Editorial board of China Electric Power Yearbook. China Electric Power Yearbook 2011 [In Chinese]. Available online: http://cyfd.cnki.com.cn/N2012030034.htm (accessed on 07 September 2016).

46. VARIAN. R.H. Intermediate Microeconomics. W.W.Norton and Company: New York, U.S., 2006.

47. Research Report on National Population Development Strategy [In Chinese]. Available online:http:// www.nhfpc.gov.cn/guihuaxxs/s 3585 u/201502/ c62a5d1a5ad54ea3b4b268777d3ae6ff.shtml (accessed on 29 November 2016).

48. DONG G.C., ZHU C. The Industrial Differences of China's TFP Growth and Influencing Factors: Based on Growth Accounting by Panel Data of 2 Digit Code Industry. Journal of Central University of Finance and Economics, 11, 62, 2013 [In Chinese].

49. SIMÕ̃S P., MARQUES R.C. Influence of regulation on the productivity of waste utilities. What can we learn with the Portuguese experience? Waste Management, 32 (6), 1266, 2012 